Ayurlog: National Journal of Research in Ayurved Science

Website: http://www.ayurlog.com $\quad$ Volume: $6^{\text {th }} \mid$ Issue: $7^{\text {th }} \mid$ Oct- Dec 2018

\title{
Role of garlic in geriatric disorders - a review
}

\author{
Vidya V. Yadav*1, Vaijnath M. Yadav²
}

1. Asst. Professor, Dept. of DravyagunaVidnyana,

L.K.R.A.M.C. Gadhinglaj, Dist-Kolhapur (Maharashtra) 416502

2. Principal \& Professor, Dept. of Rognidana \& V.V.,

Y. C. A.M. College, Aurangabad, (Maharashtra)

Mob.9421214623; Email-vmy2006@rediffmail.com

*Corresponding Author: Mob. 9881525332 Email ID - vvy2015@ rediffmail.com

\begin{abstract}
Geriatric disorder is growing problem in today's era. By 2050, one fifth of the world will be older than 65 years. As per Vagbhata 'Vata Dosha' is predominate in the body in old age. So there will be more catabolic activities taking place in the body which leads many of chronic diseases like dementia hypertension, diabetes, cardio vascular disease, etc. Conventional system of

cardiac stimulant properties. Garlic detoxifies organ system, induces relaxation $\&$ promotes longevity. Scientific studies revealed that, antioxidants drugs have definite role in the prevention of Geriatric diseases. Garlic is cheap, easily available easy for use. Keeping all these facts in mind possible role of Garlic in Geriatric care will be discuss in detail in present paper.
\end{abstract} medicine is not satisfactory in this problem as lack of holistic \& compre nsive approach towards this problem. Ayurveda has described Rasayana (Rejuvenation) Therapy which deals with old age complaints. Rasayana drugs of Ayurveda like Aamalki, Shatavari, Guduchi, Garlic, etc. are used to prevent, cure diseases \& to promote \& preserve health of the healthy. Among these herbs, Garlic (Allium sativum-Linn) has been widely used as one of the natural Rejuvenator \& dietary factor. It treats number of diseases \& considered as 'Superior medicine' for 'Vata Dosha'. Garlic has antioxidant properties, which improve general health $\&$ inhibit premature aging. In addition, it has anti-microbial, antihypertensive, antidiabetic, anti carcinogenic, aphrodisiac \&

Key words - Garlic, Rejuvenator, Geriatric, etc.

Introduction- The world population of the elderly is increasing \& by the year 2030 adults older than 65 years will comprise $1 / 5^{\text {th }}$ of the global population. In India $15 \%$ of the population are older than 65 years of age \& at least $50 \%$ of elderly in India have chronic diseases.

Aging is slow process \& it effects to the body structurally \& functionally. According to WHO the people more than 65 years of age are consider as elderly people. By the age of 50 or 60 there are so many changes takes place in the body which manifested clinically, like decrease in power, vision, memory \& locomotion 
or excertional dysponea, etc. homeostasis \& immunity also reduced, which predispose them to infectious diseases. BMR also decline with the age, nutritional condition of elder people is inadequate, so deficiency diseases are common. According to Ayurveda, in old age there is dominancy of 'VataDosha' \& 'Dhatukshya' in the body which disturbs various normal physiological functions of the body \& many pathological changes takes place. When we are going to the Ayurvedic literature, Ayurveda has proposed numerous ways \& means to overcome old age \& problems related to it. One such best way is use of, ' Rasayanas the Rejuvenation therapy as mentioned in Charaka Samhita, Susruta Samhita \& many more Ayurvedic texts.

The word Rasayana (Rasa+ Aayana) refers to nutrition \& its transportation in the body. Such a state of improved nutrition is claimed to leads series of secondary attributes like prevention of aging \& longevity, immunity against diseases, mental competence \& increased vitality of the body. Rasayana therapy not only works on physical aspects but also on mental aspects. Geriatric is a branch of modern medical science which aims at promotions of health by preventing, treating diseases \& disabilities in older adults. So to fulfill the role of geriatrics, Rasayana therapy is considered to be the main line of treatment as it prevents \& cures most of the geriatric diseases.

Rasayana is normally advised during degenerative phase which starts from around 45 years. The Rasayana drugs acts on mind, body through three modes, Rasa, Agni \& Srotasa, They promotes nutrition by direct enrichment of the nutritional quality of Rasa by improving Agni i.e. digestion, metabolism \& promoting the potency of srotasa ( microcirculatory channels in the body). Thus the main utility of Rasayana is in functional \& degenerative disorders that have chronic \& long standing nature.

\section{Various Rasayana drugs of Ayurveda like Aamalki, Shatavari,} Guduchi, Garlic,etc. are used to prevent, cure diseases \& to promote \& preserve health of the healthy. Among these herbs, Garlic (Allium sativum-Linn) has been widely used as one of the natural Rejuvenator \& dietary factor. It treats number of diseases \& considered as 'Superior medicine' for 'VataDosha'. Garlic has antioxidant properties, which improve general health \& inhibit premature aging. In addition, it has anti*hicrobial, antihypertensive, anti- diabetic, anti carcinogenic, aphrodisiac \& cardiac stimulant properties. Garlic detoxifies organ system, induces relaxation \& promotes longevity.

Scientific studies revealed that, antioxidants drugs have definite role in the prevention of Geriatric diseases. Garlic treats number of diseases along with an aphrodisiac \& rejuvenator properties but now a days it is often neglected. Garlic is cheap, easily available \& easy for use. Keeping all these facts in mind possible role of Garlic in Geriatric care was discussed in detail in present paper.

\section{2] Garlic- Overview \& Properties:}

Garlic is strongly aromatic bulb belonging to the family Liliaceae. Scientifically it is known as Allium sativum - Linn \& in Sanskrit, 'Rason'; means lacking of one 
taste i.e. sour. It is perennial herb \& cultivated for the past five thousand years in warm climate throughout the world.

Garlic is nature's gift to human beings. Since thousands of years, Garlic has been widely used as one of the natural rejuvenator, fertility enhancer \& dietary factor. It has long history \& supposed that it originates from Amruta. Renowned Greek philosopher Aristotle (384322B.C.E.) included Garlic as aphrodisiac. Although highly regarded as medicine, Garlic was avoided in cookery because of its Tamsik \& stimulant quality by upper class Hindus, Buddhist's, Jaina's, widows, $\&$ those who had taken a vow or were fasting.

\section{3] Ayurvedic properties:-}

In Ayurveda Garlic bulbs are described as 'Mahaaushadhi' \& superiof medicine for 'VataDosha'. According Ayurveda, it contains five tastes except sour. It is hot in potency $\&$ pungent in post digestive taste, unctuous, sharp \& heavy; it pacifies Kapha \&Vata \& aggravates Pitta \&Rakta. Due to its properties it cures common diseases \& increase longevity. It is appetizer, aphrodisiac, rejuvenative, digestive, carminative, cardiac stimulant, expectorant, analgesic, anthelmintic, \& foremost for disease free State. It is clarifier of memory, intellect, strength, age, complexion \& eyes (sight) \& cleaner of channels. It is producer of Shukra (sperm\& spermatic fluid), \& Shonita (ovum \& ovarian hormones.), Garbha (pregnancy) \& is beneficial for hair; also it is best for stability of life . It also used in fracture, diseases of bone, all diseases of vata, cough, skin diseases, cataract, night blindness, indigestion, dysuria, fistula in ano, diseases of spleen \& to increase intellect, agni ( digestive power) \& strength.

$$
\text { Garlic's Rejuvenator \& }
$$

aphrodisiac action is mentioned in Charka Samhita, Susruta Samhita, Ashtanga Sangraha, Kashyapa Samhita \& Bhavprakashanighantu but Aacharya Kashyapa gives detail description of uses of garlic \& its pharmaceutical preparation in 'Lasunkalpaaddhya' of Kalpasthana. Kashyapa mentioned that if women eat Garlic their beauty, progeny \& strength never decreases, breast neither become lax $\&$ their youth becomes stable. Garlic also cures disease of sacral region, hips \& other parts of body \& if women consume garlic she neither becomes infertile nor look ugly. The man becomes stout, intelligent, with good longevity, with good progeny, does not get tired in coitus \& retains hukra.. In this way, we conclude that farlic is one of the best rejuvenator which capable of stabilising the age \& it cures the problems leading to old age.

Methods, contraindication, types, preparations, doses \& period of use of Garlic has been also mentioned in detail in KashyapaSamhita.

4] Chemical constituents:-It contains water, protein, carbohydrates \& other substances like calcium, phosphorous, iron \& vitamin B-complex. It also contains volatile oils \& compounds of sulphurs, which are responsible to its sharp odor. When crushed, garlic yields allicin, an antibiotic\& antifungal compound. It also contains diallyldisulphide, diallyltrisulphide, vinyldithins, ajoene, allixin, etc.

5] Garlic \& Human Health:-Garlic has been considered as disease preventive food 
$\&$ its effect on human health have been studied.

\subsection{Effect on cardiovascular disease-}

The effect of garlic on the cardio vascular system have been attracting lot of interest in recent times. An increase in the amount of cholesterol in the body can lead to the formation of atherosclerotic plaques and this is a risk factor for both heart attacks and strokes. Low-density lipoprotein (LDL) cholesterol levels can greatly be reduced by Garlic without affecting the good High-density lipoprotein (HDL) cholesterol levels. The mode of action is said to be that Garlic blocks the liver from making too much LDL because of its bioactive ingredients. The high levels of cholesterol result in an increase in freeradical producing peptides. Reactive oxygen species (ROS) and oxidative stress (OS) levels are also key markers in CVD. and by decreasing these levels the onset heart disease can be delayed.

Garlic can delay the onset of heart disease due to its antioxidant properties. It reduces the amount of cholesterol in the body and by doing this the heart becomes more protected. Garlic also plays an important role in maintaining the structure and efficacy of endothelial cells and endothelial function. The administration of AGE inhibits the progression of coronary artery calcification and reduces the risk of a myocardial infarction or a heart attack. With the onset of menopause, fat, cholesterol levels \& degree of oxidative stress are increased. Garlic has shown to reduce all these risk factors which are responsible for CVD .

\section{..5.2 Effects on blood pressure-} Hypertension has been considered to be the most important biomarker in the onset of CVD. Clinical study shows that Garlic significantly reduce B.P. in hypertensive patients when compaired to those receiving a placebo. The antihypertensive effect of garlic is said to be due to the fact that the nitric oxide (NO) system is more active than the rennin-angiotensin system. $\mathrm{NO}$ and Hydrogen sulphide (H2S) play major roles in the progression of diseases, both $\mathrm{NO}$ and $\mathrm{H} 2 \mathrm{~S}$ are considered to be important vasodilators. In a recent study both serum $\mathrm{NO}$ and $\mathrm{H} 2 \mathrm{~S}$ were measured in diabetic rats and it was shown that chronic administration of garlic normalised both gaseous molecules and reduce BP.

The administration of AGE improved the condition of arteries as prevented the stiffening of the blood vessels which is a key marker in aging. By doing this it also improves erythrocytes which are the main component of blood. herefore improves peripheral circulation caused by AGE could be one of the causes of lowering BP, but RG showed to cause an increase in erythrocyte deformation and could lead to anaemia.

\section{3 effects on diabetes - The} hypoglycaemic effect that garlic is due to the presence of allicin and sulphur compounds. Studies have shown that the oral administration of raw garlic significantly reduced blood glucose levels and improved insulin sensitivity in garlic treated rats. Administration of aqueous garlic in patients with Type 1 diabetes has been reported to increase insulin sensitivity. Furthermore, metabolic complications such as increased serumtriglyceride, insulin and uric acid levels usually observed in diabetic rats were normalised after garlic administration. A study has shown that allicin administered 
for 2-3 weeks reduced weight gain \& glucose levels in fructose fed rats.

\subsection{Effects on dementia and the brain-}

Individuals living with dementia have a much higher level of homocystein than healthy people and there is a significant link between high levels of homocystein and loss of cognition. It has also been indicated that the intake of Aquous Garlic extract (AGE) decreases homocystein levels. AGE has also been shown to possess anti-aging properties, in studies AGE prevented the deterioration of the brain's frontal lobe, and enhanced learning and memory retention.

Effects on cancer- Garlic is said to have chemo-preventive properties and its effects have been closely studied on various cancers. The major chemicals found in Garlic which prevents cancer are allicip (dially 1 disulphide oxide), S-ally cysteine, S-ally1 mercapto cysteine \& selenium. Ally1 sulphides can influence a number of molecular events involved with cancer. These include inhibiting mutagenesis, blocking carcinogen DNA adduct formation, scavenging free radicals, suppression of tumour cell growth through stimulation of immunoresponder cells. In 1990 the U.S. National Cancer Institute declared that Garlic may be the most potent food having cancer preventing properties. The formations of tumours in vitro and in vivo were shown to be greatly decreased after the administration of fresh garlic.

\subsection{Effects on reproductive system-}

For thousands of year Garlic has been widely regarded as one of the top natural fertility enhancer for men.It contains selenium which is an anti-oxidant mineral that's necessary for properly shaped sperm $\&$ to maintain sperm count $\&$ it has vit-B6 which fortifies the immune system \& is responsible for formation of male sex hormone i.e. testosterone.

Garlic is beneficial in the treatment of erectile dysfunction \& impotence. It contains hundreds of minerals \& nutrients. It is very likely that no one ingredient is the active ingredient. To obtain an erection an enzyme is required called Nitric oxide synthase \& compounds in garlic stimulates the production of this enzyme in people who suffer from low level of it. Garlic improves blood circulation significantly \& keeps veins \&arteries youthful, but that is only one way it helps with impotence.

However, the impact of Garlic has not been clearly defined. Some studies have reported that Garlic improves male exual function \& has beneficial effect in the recovery of testicular function. However, other authors have shown that this plant impairs testicular function (such as inhibition of testosterone production.) \& has spermicidal effect on spermatozoa The main difference $\&$ the possibly the reason between different results could be the lack of standardization between research model \& different amount of garlic gives to test subject.

Therefore studies have shown that in proper doses \& preparation, intake of garlic improves seminal fluid \& sperm count \&balance normal hormonal level as well.

Garlic is useful to delay the menopause. New research shows that taking garlic during pregnancy can cut the risk of pre-eclampsia. Studies shows that garlic may help to boost the birth weight 
of babies There is so much more information about this wonderful herb \& lot of research still going on. Surprisingly, the way Garlic is prepared appears to affect its healing qualities. When the clove is cut or crushed, an enzyme contained within plant cells combines with an amino acid, which has been shown to kill 23 types of bacteria, including salmonella. When Garlic is heated, a different compound is formed that is good blood thinning agent, preventing arteries clogging, avoiding blood clots that could lead to heart attack or stroke.

\section{Discussion:}

Garlic is an Indian traditional Ayurvedic drug used as rejuvenating medicine in aging condition. As per Vagbhata, Vata Dosha is predominant in old age which disturbs various normal physiological functions of the body \& man pathological changes takes place. It creates cholesterol \& decrease plate late many degenerative, immunological, neurological diseases in the body.

Acharya Susruta defined Rasayana as 'Vayasthapana' which retards aging process. Garlic due to its properties, cures common diseases, increases longevity, is appetizer, aphrodisiac \& foremost for diseases Free State. It is clarifier of memory, intellect, strength, age (longevity), complexion \& eyes. The teeth, flesh, nails, moustache/ beard hair, complexion, age \& strength of the born human never decline \& thus youth become stable. Garlic also treats number of diseases like dementia, arthritis, CVD, hypertension, diabeties, cancer etc. As it is superior medicine for Vata dosha it treats all types of vata diseases.
Garlic contains more than 100 biologically useful secondary metabolites \& sulphur containing compounds. It is excellent source of manganese, selenium \& B- vitamins. Clinical experiments in recent times have not only confirmed several ancient beliefs about extraordinary healing value of this plant but also brought into light many of its lesser known benefits.

Garlic contains selenium which is an antioxidant mineral that's necessary for properly shaped sperm \& to maintain sperm count \& it has vit-B6 which fortifies the immune system \& is responsible for formation of male sex hormone i.e. testosterone. It is also useful for erectile dysfunction \& impotency.

Numerous studies have demonstrated that regular consumption of Garlic lowers serum triglycerides \& LDL aggregation. It has also been found to increase the HDL cholesterol, fibrinolysis $\&$ stimulate the production of nitric oxide in the lining of the blood vessel wall \& reduces the risk of heart attack \& stroke.

Research shows that regular use of Garlic increases the production of antioxidant enzymes that hold back the activity of many cancer \& tumor producing substances. Garlic is able to protect against certain degenerative effect of rheumatoid arthritis- all of which are caused by an imbalance of free radicals \& body protective defenses. It has also been found to be having anti oxidant, antiinflammatory, anti -bacterial, anti-viral activity \& is effective against many drug resistant strain. Also it is useful in weight control. Garlic detoxifies organ system, induces relaxation \& promotes longevity. 
Thus by the use of Garlic one becomes free from diseases $\&$ becomes healthy.

\section{Conclusion:}

Present review highlights the various therapeutic uses of Garlic mentioned by Ayurveda. It is concluded that Garlic is important dietary herb which helps to cure etiological factors of Geriatric diseases \& used as a Rejuvenator..

\section{References:}

1. Makar RS, Toth TL. The evaluation of infertility American Journal of Clinical Pathology, 2002; 117 (Suppl): S95103

2. Susrut ,SusrutSamhitaSutrasthana 46 1244- 245, Su. Sha.2/33 Edited by KavirajAmbikadattaShastri (Edition2004), Chaukhamba Sanskrit Sansthan, Varanasi.

3. HiralalKonar, 'Datta's Text Book Gynacology' Chapter-17 Delhi, Jaypee Brothers Medical Publishers $1^{\text {st }}$ edition 2014.

4. Makar RS, Toth TL. The evaluation of infertility American Journal of Clinical Pathology 2002; 117 (Suppl): S95-103

5. Agnivesh, CharakaSamhita, revised by Charak\&Drudhabala, Sutra sthana 27/176 . commentary by, Pt. K. Shastri, \& Dr. G. Chaturvedi (Edition 1998) , ChaukhambaVishwabharati, Varanasi.

6. Vagbhata, Ashtangrudaya, Sutrasthana 6//109-111, 7/,162-165 ; U -39/111$129 \& \quad 107-127, \quad 133-134$, by BrahamanandTripathi,(Edition- 2007), Chaukhamba Sanskrit Pratishathana, Varanasi.

7. MaharshiMarichaKashyapa

,KashyapaSamhita , summarized by AchryaVrudhajivaka, KalpaSthana,
1/4-115(

edition-2008),

ChaukhambaVishwabharati, Varanasi.

8. V.M.GogateDravyaguna, $1^{\text {st }}$ editon Pune, VaidyamitraPrakashan 2008.

9. Dr. G.S. Pande (Editor), Dr. A. C. Chunekar( Commentor)

,'BhavprakashNighantu'(Hindi)

ChaukhambaBharatiAcadamy, reprint 2006.

10. Pandya K, Solanki B, Maniar K, Gurav $\mathrm{N}$, Bhatt S. Natural herbal supplements- A study on their nutritional value and their phytochemical constituents. International Journal of Pharmaceutical Sciences and Research 2011; 2:148094

11. Ankri S, Mirelman D. Antimicrobial properties of allicin from garlic, Microbes and Infection, 2, 1999, 125-129

2. Oi Y, Imafuku M, Shishido C, Kominato Y, Nishimura S, Iwai Garlic supplementationincreases testicular testosterone and decreases plasma corticosterone in rats fed a high protein diet. Journal of Nutrition 2001; 131:2150-2156

13. Hammami I, El May M. Impact of garlic feeding(allium sativum) on male fertility,Andrologia 2012; 1-8.

14. Hammami I, Amara S, Benahmed M, El MV, Mauduit $\mathrm{M}$ and Mauduit $\mathrm{C}$. Chroniccrude garlic-feeding modified adult male rat testicular markers: mechanisms of action.Reproductive Biology and Endocrinology 2009, 7:65.

15. Eteng MU, Onwuka FC, Akpanyung EO, Osuchukwu NC, Bassey SC, NwankpaP.Reversal of cadmium induced toxicity following dietary supplementation with garlic,ginger and cabbage in male Wistar rats. Journal of 
Natural Products and PlantResources 2012; 2 (1):169-174.

16. Hammami I, Nahdi A, Mauduit C, Benahmed M, Amri M, Ben Amar A, Zekri S, ElMay A, El May MV. The inhibitory effects on adult male reproductive functions of crude garlic (Allium sativum) feeding. Asian Journal of Andrology 2008;10:593601.

17. Ogbuewu IP, Unamba-Oparah IC, Odoemenam VU, Etuk, IF and Okoli IC, The potentiality medicinal plants as the source of new contraceptive principles in males.New American Journal of Medical Sciences 2011; 3(6): 255-263.

18. Prediction and prevention of preeclampsia.,Briceño-Pérez $C$, Briceño-Sanabria L, Vigil-De Gracia P, Hypertens Pregnancy. 2009 May; 28(2):138-55.[PubMed]

19. Garlic and Its Effects on Health wit Special Reference to the Reproductive System

20. http://dx.doi.org/10.5772/57191(277)

21. Ankri S, Mirelman D. Antimicrobial properties of allicin from garlic. Microbes and Infection 1999; 2: 125-129 Imai, J, Ide, N., Nagae, S., Moriguchi, T., Matsuura, H. \&Itakura, Y. Antioxidants and free radical scavenging effects of aged garlic extract and its constituents. Planta Medica 1994; 60: 417-420

22. Moriguchi, T., Saito, H. \&Nishiyama, N. Anti-aging effect of aged garlic in inbred brain atrophy model mouse. Clinical Experimental Pharmacology and Physiology 1997; 24: 235-242

23. Pandya K, Solanki B, Maniar K, Gurav $\mathrm{N}$, Bhatt S. Natural herbal supplements- Astudy on their nutritional value and their phytochemical constituents. InternationalJournal of Pharmaceutical Sciences and Research 2011; 2:148094

24. Sobenin I, Pryanishnikov V, Kunnova L, Yevgeny, Rabinovich A, Martirosyan D, Orekhov AN. The effects of time-released garlic powder tablets on multifunctional cardiovascular risk in patients with coronary artery disease. Lipids in Health and Disease 2010; 9:119

25. Hornick B, Yarnell E. Medical uses for garlic,

http://health.howstuffworks.com/welln ess/

naturalmedicine/alternative/medicaluses-for-garlic-ga.htm (acc on 5th august 2013).

26. Ried K, Frank OR, Stocks NP, Peter Fakler1 and Sullivan T. Effect of garlic on blood

pressure: A systematic review and meta-analysis. BMC Cardiovascular Disorders 2008, 8:13

27. Elkayam A, Mirelman D, Peleg E, Wilchek M, Miron T, Rabinkov A, Oron-Herman

M, Rosenthal T. The Effects of Allicin on Weight in Fructose-Induced Hyperinsulinemic,

Hyperlipidemic, Hypertensive Rats. American Journal of Hypertension 2003; 16:1053-1056

28. Cerella C, Dicato M, Jacob C, Diederich M. Chemical properties and mechanisms determiningthe anticancer action of garlic-derived organic sulfur compounds. Anticancer

29. Agents Medicinal Chemistry 2011;11:267-271 
Cite article:

Role of garlic in geriatric disorders - a review

Vidya V. Yadav, Vaijnath M. Yadav

Ayurlog: National Journal of Research in Ayurved Science- 2018; (6)(7): 1-9 